\title{
MANAGEMENT OF THE PATIENT WITH MYASTHENIA GRAVIS FOR THYMECTOMY
}

\author{
Leonard C Jenkins, BA, M D, C M, $\mathbb{F} \mathbb{R} \mathbf{P}(\mathrm{C})$, \\ Jone Chang, $M \mathbb{D}, \mathbb{F} \mathbb{R} \mathbf{P}(\mathrm{C})$, AND \\ Horace B Graves, BA, MD, CM, FRP P (C)
}

\begin{abstract}
Whatever is unknown is magnified
TACITU,

The Life of Agricola, Section 30

A. 54
\end{abstract}

\section{INTRODUCTION}

THE VALUE OF thymectomy in myasthenia gravis remains controversial ${ }^{1}$ Despite the lack of a clear understanding of the aetiology of this disease, it is generally accepted that the thymus has some causal or contributory relationshrp to myasthemia gravis and that thymectomy should be performed in selected patients Many patients demonstrate improvement following this operation Furthermore, drug therapy for myasthenia gravis, chiefly with anticholinesterases, is only partially effective and may frequently be accompanied by unpleasant or senous side-effects Surgery and anaesthesia may also can ry a significant operative morbidity Nevertheless, $m$ one large series of cases the mortality rate was even higher in those patients treated with anticholinesterases alone than in those having thymectomy ${ }^{1}$

In this presentation we shall not attempt to discuss the interesting background for thymectomy in myasthenia gravis, ${ }^{2} 3$ but rather to outline our management of these patients

\section{METHOD}

We shall present a method of management from our clinical expenences over the past fourteen years (1950-63 inclusive) involving twenty-one myasthenia gravis patients who have undergone thymectomy The salient features of the patients in this series are tabulated in Table $\mathbb{I}$ This study has been divided, retrospectively, into two periods because our managernent durnng the last five years (1959-63 inclusive) has been altered significantly from that of the first mine years $^{4}$ (1950-58 inclusive) because of the influence of three recent majo: advancements

(1) the usage of the decamethonium diagnostic test in a myasthenia gravis diagnostic clinic,

From the Department of Surgery (Sub-section Anaestheblology), Vancouver General Hospital, and the Faculty of Medicine, Unversity of British Columbia, Vancouver, Britush Columbia Presented in part at the Annual Meeting, Royal College of Physicians and Surgeons, Canada, Quebec City, January 17, 1964 
(2) the improvement in the assessment and the management of respiratory insufficiency,

(3) the avoidance of anticholnesterase diugs as treatment in the immediate and early postoperative recovery period

The two groups of patients are comparable (Table I) There were eleven patients in the first nine years and ten patients in the last five years of the study period There was a total of sixteen females, eight in each penod, with simular age distribution There was a total of five males, three in the first group and two in the latter period All the males had either a thymic tumour or hyperplasia of the thymus Distinctive pathological lesions were absent in four patients of the initual group and in two panents duing the last five years Prophylactic tracheostomy was not performed durng the first nine years, but three of the last ten patients had prophylactic tracheostomies

\section{TABLE I}

21 Patients with Myasthenua Gravis for Thymectomy (1950-63)

\begin{tabular}{|c|c|c|c|}
\hline & & $\begin{array}{c}1950-58 \\
\text { (11 patients) }\end{array}$ & $\begin{array}{c}1959-63 \\
(10 \text { patients })\end{array}$ \\
\hline Sex & $\begin{array}{l}\mathrm{F} \\
\mathrm{M}\end{array}$ & $\begin{array}{l}8 \\
3\end{array}$ & $\begin{array}{l}8 \\
2\end{array}$ \\
\hline Age & $\begin{array}{l}\text { Range } \\
\text { Average }\end{array}$ & $\begin{array}{c}10-54 \\
314\end{array}$ & $\begin{array}{c}16-52 \\
325\end{array}$ \\
\hline Stage & $\begin{array}{ll}1 & \text { Resistance (ocular) } \\
2 & \text { Dual block (generalized) } \\
3 & \text { Refractory (myopathic }\end{array}$ & $\begin{array}{r}1 \\
10 \\
0\end{array}$ & $\begin{array}{l}1 \\
8 \\
2\end{array}$ \\
\hline Thymus & $\begin{array}{l}\text { Hyperplastıc } \\
\text { Tumour } \\
\text { Irradiated }\end{array}$ & $\begin{array}{l}3 \\
4 \\
1\end{array}$ & $\begin{array}{l}4 \\
4 \\
0\end{array}$ \\
\hline \multicolumn{2}{|c|}{ Tracheotomy-prophylactic } & 0 & 3 \\
\hline
\end{tabular}

The patients were representative of all three clinical forms on stages of myasthenı gravis (Table I) There were no myopathic refractory palients in the first nine years, but two in the last five yedrs These patients are not generally considered surtable for thymectomy, as the incidence of improvement is low In addition, they may present grave problerns in anaesthetic management

Not all the patients in this series had a decamethonium diagnostic test, but recently we have found this test to be of value as an additional adjunctive confirmatory procedure The neostgmine and ediophonum (Tensilon) tests are often equivocal and the "curare test" is of limited value in the mild case of myasthema gravis The decamethonum diagnostic test has consistently demonstrated its definituve diagnostic value as it enables the identification of three distunct phases or stages in the developrnent of myasthenia gravis This ands in assessing the prognosis and subsequent type of management of an individual case The application of this test in a myasthenia gravis diagnostic clinic has been recorded in detal ${ }^{5}$ of prime importance is the fact that this test has also 
provided a contmuity of personnel from the preopelative clinic to the operating room, as an anaesthetist is a member of the diagnostic team in association with a neurologist and a physiatrist

The anaesthetic and surgical management of my asthenia giavis patients for thymectomy presents serious problems These pitients may have impaired activity of their respuratory system, they are frequently of poor nutritional status, they are susceptible to infecton, they have a labile emotional status, and they have altered reactions to many drugs used before surgery, durng surgery, and after surgery (for example, antibiotics, narcotics, muscle relaxants, and general anaesthetics)

\section{A Preoperative Preparation of the Patient}

Admission to hospital a few days before operation is advisable Rest reduces drug sequirements The patient's general response to oral anticholinesterase therapy can be assessed

The various anticholnesterases used in the treatment of myasthenia gravis are tabulated in Table II Their equivalent doses are summarzed in Table III The

\section{TABLE II}

Anticholinesterases Used in the Treatment of Myasthenia Gravis

\begin{tabular}{ll}
\multicolumn{1}{c}{ Genenc name } & \multicolumn{1}{c}{ Trade name } \\
\hline Neostrgmine bromide & Prostigmin broinide \\
Neostigmine methyl sulphate & Prostigmin methyl sulphate \\
Pyndostigmine bromide & Mestinon \\
Ambenonium chlonde & Mytelase \\
Edrophonum chlonde & Tensilon \\
Bis-neostigmine & Hexamanum \\
Bis-pyndostagmine & Phosphate iodide \\
Echothiopate iodide & \\
\hline
\end{tabular}

minimal dose is determined as that dosage which will provide an adequate sespiratory exchange (tidal volume $(\mathrm{T} V)=300 \mathrm{c} \mathrm{c}$ or more, vital capacity ( $\mathrm{V} C$ $=1800 \mathrm{cc}$ or more as measured by Wright respirometer), normal $p \mathrm{CO}_{2}$ and pHI by the Astrup method, and the ability to chew and swallow This assessment is of help in anticipatung those cases which will more than likely need mechanical respiratory assistance and/on tracheostomy preoperatively or postoperatively

TABLE III

Equivalent Doses of Commoni y Used Anticholinesterases

\begin{tabular}{|c|c|c|}
\hline Drug & $\begin{array}{l}\text { Oral dose } \\
\text { (mg ) }\end{array}$ & $\begin{array}{c}I / M \text { or } I / V \text { dose } \\
\text { (mg) }\end{array}$ \\
\hline Neostigmune (Prostıgmin) & 15 & 05 \\
\hline Pyndostigmune (Mestinon) & 60 & 20 \\
\hline Ambenonium (Mytelase) & 6 & None avanlable \\
\hline
\end{tabular}


On the day of operation the anticholinesterase medication is reduced Decreasing or omitting this medication will influence favourably the acetylcholineinsensitive state and decrease the resistarice of the patient to anticholmesterases This provides for an easier adjustment of, and response to, such medication, if it is necessary in the postoperative period Also, following thymectomy, the majority of patients have a short-lastung ( 18 to 48 hours) remission In contrast, the administration of a high dose of preoperative anticholinesterase may cause a "cholinergic crisıs" postoperaiıvely

Respuratory depressant drugs are avoıded in pre-anaesthetic medication Morphine sulphate respiratory depression is, potentated by neostigmine (Prostigmin) ${ }^{2}$ Atropine and scopolamine are given for their drying effect on the respuratory tract and reduction of potentially harmful reflex effects from surgery and anaesthesia

\section{$B$ The Conduct of Anaesthesia}

Induction is usually with intravenous thiopentone via an indwelling peicutaneously inserted No 16 Rochester polyethylene catheter attached by extension to a three-way disposable plastic stopcock This arrangement permits the administration of drugs, flud, electrolytes, and blood with ease, either simultaneously or separately, both during surgeny and in the postoperative period The use of neuromuscular blocking agents before endotracheal intubation is not always necessary Adequate topical anaesthesia of the pharynx and larynx under general anaesthesia is usually all that is required If relaxation is necessary to facilitate endotracheal intubation, a single 04 to $06 \mathrm{mg} / \mathrm{kg}$ dose of succinylcholine may be used Further use of the muscle relaxant is not required A cuffed endotracheal anaesthesia is essential, in order to facilitate adequate ventilation, removal of accumulated tracheobronchial secretions, and avoidance of gaseous stomach distention Maintenance anaesthesia is with cyclopropane or halothane (Fluothane) Respiration is controlled manually or with a mechanical ventilator Thymectomy is attained through a median sternotomy incision

If we anticipate that the patient's spontaneous iespuatory activity or cough mechanism will be inadequate postoperatively, a prophylactic tracheostomy is performed before the removal of the endotracheal tube, at the completion of the operation The site of the tracheostomy is slightly higher than usual to avoid contamination of the mediastinum A tracheostomy tube with inflatable cuff (James tube) is used This will allow intermittent positive pressuie (I P P) respiratory assistance with a mechanical respirator Controlled or assisted respiraton is well tolerated in these patients As the majonty of postoperative deaths in myasthenics are due to respiratory complications, it is suggested that the indications for prophylactic tracheostomy be liberal for the myasthenic patient

\section{$C$ The Postoperatwe Recovery Period}

Following thymectomy, the most frequent causes of postoperative morbidity and mortality can be related to $(1)$ respiratory or (2) circulatony complications or (3) myasthenic emergencies of which over-medication with anticholinesterases ("cholinergic crisis") is the most common 


\section{Mantenance of Adequate Respiration}

Fastidlous care is given to the respiratory tract during the early postoperative period If the respiratory exchange is adequate, the endotracheal tube may be removed and the patient allowed to breathe spontanecusly Patents with borderline respiratory exchange may be carned for a 24 -hour period with mechanical assistance to respuration via an endotracheal tube If the tidal volume was less than $300 \mathrm{cc}$ and the vital capacity less than $1800 \mathrm{cc}$ preoperatively, then a tracheostomy has usually been done The patient's respirations are assisted or controlled by $I \mathbb{P} P$ respiration with $40-60$ percent $\mathrm{O}_{2}$ initially, and then air, saturated with warmed nebulized water vapour, until minute volume $(\mathrm{MV}), \mathrm{TV}, \mathrm{V} \mathrm{C}, \mathrm{pH}$, and $p \mathrm{CO}_{2}$ monitoring indicates that spontaneous respirations are adequate

In these patients, there are many variable factors in this period that may result in respiratory difficulty, such as lack of anticholinesterases, thoracic splinting from operative pain, emotional upset, pneumothorax, pneumomediastinum, haemothorax, atelectasis, or residual depression frorh anaesthesia We do not attempt to titrate the patient's anticholinesterase requirement in order to maintain muscle strength of adequate respiratory exchange, as the other factors may be responsible for this difficulty Overenthusiasm with anticholinesterases may then result in "cholinergic crisis," a senous and unnecessary complication This regime without anticholinesterases may involve several days' management As the patient's condition improves, with or without gradual introduction of oral antcholinesterase (by nasogastric tube if necessary), and his spontaneous respilatory activity becomes adequate, the use of the mechanical ventilator can be gradually discontmued

\section{Support of Cuculation}

Specific morphological lesions have been described in the myocardium of myasthenics ${ }^{7}$ These lesions may be the cause of suclden, unexpected death, as reported in some series Careful attention, therefore, is given to the state of the circulation, with regard to blood volume, haemoglobin, fluid and electrolyte requirements Significant amounts of fluid may be lost through mediastinal or chest drainage

\section{Management of Myasthenic Emergencies}

The mechanım underlyng myasthenic emergencies may vary, but whatever their cause, when untreated, their end result is usually respiratory failure The first and most important factor in their management is the prompt instituton of adequate respiratory exchange This will keep the patient alive until the nature of the emergency can be diagnosed and it can be treated with approprate drug therapy

Depending on their pathophysiologic basis three types of myasthenic emergencies may be distinguished

(1) "Myasthenic crisis" from under-medication

(ii) "Cholunergic crisis" from over-medication

(111) Development of an acetylcholine-insensitve state ${ }^{8}$ This may simulate 
(1) "myasthenic crisis" or be associated with (11) "cholınergic crisis" It can only be diagnosed from the effects of therapeutic trials with edrophonum or other anticholinesterases Complete withdrawal of anticholnesterases and/or prolonged administration of $d$-tubocurare with controlled respiration are indicated in order to "rest" the myoneural junction"

Drug therapy in these myasthenic emergencies is directed towards

(1) Control of muscarinic side-effects (in "cholinergic crisis") with an inital intravenous dose of atropine 04 to $10 \mathrm{mg}$, and subsequent 03 to $04 \mathrm{mg}$ doses every three to five minutes until the desired effect is obtained

(11) Improvement of muscle strength (in "myasthenic crisis") If $10 \mathrm{mg}$ intravenous edrophonium (Tensilon) indicates improved muscle strength, cautous intravenous administration of neostigmine $(03 \mathrm{mg})$ or pyridostigmine (12 mg ) can then be tried after prior injection of atropine (04-06 mg) Fractional doses thereafter of the anticholinesterases are usually half the initial dose

(1i1) Prevention of infection of the iespiratory tract Because of the myasthenic's susceptibility to pneumonid and other infections of the respiratory tract, antibiotics may be given prophylactically It is well worth remembering that some antibiotics, for example, neomycin, streptomycin, and polymyxin $\mathrm{B}$, have a mild, but definite, non-depolanzing neuromuscular effect which may accentuate the neuromuscular block in myasthenics sensitive to these agents

\section{Illustrative Case-Pattent E M J}

This patient epitomizes several of the many problems that are associated with the care of the patient with myasthenia gravis

A 52-year-old, white housewife, apart from a known irregularity and mequality of pupils since 1953 and isolated episodes of untreated paroxysmal auricular tachycardia, was well untl November 1960, when she experienced a sudden onset of choking sensation, difficulty in clearing mucus from her throat, slurred speech, difficulty in swallowing, and ptosis of eyelids These manifestations progressed intemittently over the next two years She arrived in the emergency ward at Vancouver General Hospital on December 30,1962, with laboured respirations, nasal slurred speech, weakness of the masseters, and bilateral facial weakness She also had generalized muscle weakness, especially of the neck muscles She appeared to have diffuse wasting of her limb muscles She had occasional ventricular extrasystoles Her normal weight was $130 \mathrm{lb}$, but she now weighed $89 \mathrm{lb}$ The Tensilon test was negative and the cerebrospinal fluid pressure was normal She was tentatively diagnosed as a bulbar palsy On January 4, 1963, she developed a bout of paroxysmal aun icular tachycardia, for the first tume in the presence of a physician This was easily controlled with medication On January 5 , she developed a right lower lobe atelectasis She became dyspnoeic and cyanotic She was not able to cough $\mathbb{A}$ tracheostomy was performed under local anaesthesia and oxygen On return to the $P A \mathbb{R}$ she had a cardiac arrest External cardiac massage was begun immediately followed by open-chest resuscitation Under direct vision the heart was seen to be in complete standstill Four manual compressions of the left ventricle instituted a strong, forceful myocardial contraction The B P returned to normal She was placed on I P P assisted respirainon through the James tracheostomy tube By January 10 her speech and swallowing had improved markedly She was able to cough reasonably effectively

An electromyographic study on January 2\% suggested myasthenia gravis There was no electromyographic evidence of denervation or of myopathic changes in the frontalls, masseter, or orbicularis oris muscles Her condition improved appreciably on a trial dose 
of Mestinon $60 \mathrm{mg}$ She was discharged, much improved, on January 23, 1963, with Mestunon $60 \mathrm{mg} \mathrm{B} \mathrm{I} \mathrm{D}$

On March 14, 1963, she was readmitted because of sudden severe precordial pain However, her B P, heart rate, and E C G were found to be normal She now weighed $80 \mathrm{lb}$ She was also now receiving atropine medication because of the gastrointestunal muscarinic side-effects of Mestinon

On April 2 the decamethonium test was performed Following the inital dose of 05 $\mathrm{mg}$ decamethonium (one half the usual given) she became apnoeic Tensilon $10 \mathrm{mg}$ and prostigmme $10 \mathrm{mg}$ improved her respiratory activity but it remained inadequate with a tidal volume of only $150 \mathrm{cc}$ An endotracheal tube was inserted She was given assisted ventilation and observed in the intensive care urit The following day, April 3, her spontaneous tadal volume was still only $150 \mathrm{cc}$ On April 5 a tracheostomy was performed Durng induction of anaesthesia for this procedure, she became hypotensive, her heart rate was $160 / \mathrm{min}$ There was distention of nirck veins She was digitalized Post-tracheostomy she was gradually weaned from the mechancally assisted respirator On nasogastric feedings she gained eight pounds Hel haemoglobin was $146 \mathrm{gm}$, electrolytes and plasma proteins were normal

Because of the increasing muscarnnic side-effects of anticholmesterase treatment, the need for ever-mcreasing doses of medication, and the suggestion on tomography that there was a thymic tumour, a thymectomy was performed on April 22 A thymoma was removed

This patient was managed in the immediate preoperative, operative, and postoperative period as outlined in our method, with an uneventful course She was discharged improved on May 10, 1963

When seen in OPD in December 1963, she weighed $98 \mathrm{lb}$, was eatng well, and ambulatory She still required anticholnesterase treatment, but it was much reduced and effective, without side-effects

\section{Results and Discussion}

Table IV suggests that following this form of management durng the past five years (1959-63 inclusive) operaive risk has been reduced from that durng the previous nine years (1950-58 inclusive) of this period of study

TABLE IV

Operative Mortality and Morbidity in 21 Patients With Myasthenia Gravis and ThyMectomy

\begin{tabular}{lcc}
\hline & $\begin{array}{c}1950-58 \\
\text { (11 patients) }\end{array}$ & $\begin{array}{c}1959-63 \\
\text { (10 patients) }\end{array}$ \\
\hline Mortality & 1 & 0 \\
Morbidity & & \\
Pneumothorax with & 4 & 0 \\
$\quad$ atelectasis & 4 & 1 \\
Pneumonia & 3 & 0 \\
Emergency tracheostomy & 3 & 0 \\
"Cholinergic crisis " & 9 & 9 \\
Improved & 2 & 1 \\
Not improved & & \\
\hline
\end{tabular}


During 1950-58 there was one death, during "cholinergic crisis" Four patients had postoperative pneumothorax and pneumonia This high incidence may be related partly to intercostal thoractomy, the usual approach durng this period of study Also, prophylactic tracheostomies were not performed Three required emergency tracheostomy in the postoperative period Three had episodes of "cholmergic crisis"

During 1959-63 there were no deaths, despite the fact that two of the ten patients in this senes were poor-risk myopathic, refractory patients Staphylococcal pneumonia developed in one patient secondary to an infected tracheostomy There were no complications with "cholinergic" or "myasthenic" crisis

The over-all mortality rate was 4 per cent in this series This compares favourably with an accepted operative mortality for thymectomy in most institutions of $4-5$ per cent This figure may be doubled for myasthenics with tumours, ${ }^{1}$ and eight of the twenty-one patients in our series had tumours Drug-therapy management, alone, may carry high mortality rates, as one large series ${ }^{1}$ demonstrated a 16 per cent mortality rate

Improvement (that is, full remission, or with only minor weakness or only subjective improvement) occurred in eighteen of the twenty-one patients Three patients were not improved

Until the aetıology and pathogenesis of myasthenia gravis is known, the debate on the usefulness of thymectomy will undoubtedly continue Certainly, the recent auto-smmune reaction theory of myasthenia gravis ${ }^{1011}$ attractively correlates the thymus and a defect in neuromuscular transmission In this theory it is believed that the myasthenic patient develops antibody aganst some component of skeletal muscle The thymus reacts to proten derned from the motor endplate This antibody may become fixed to the muscle membrane and in turn bind serum complement to this structure causing cytolytic or subcytolytic alterations These changes may decrease sensitivity to acetylcholine and cause the defect of neuromuscular transmission of a reversible ol irreversible nature Antibody production may occur in the absence of the thymus, suggesting that perhaps the thymus has seeded its antbody-producing lymphocytes (thymocytes) to other areas, such as the spleen and lymph nodes, which may then take over the functon $^{1}$ The development or persistence of myasthenia gravis months or years following total removal of the thymus could be explained by the presence of active thymocytes in the spleen or lymph nodes This conceivably could limit the effectiveness of removal of what was perhaps the initial source and site of the auto-immune response and suggests the efficacy of removing the spleen, in addition to the thymus

\section{SUMmary}

A method of management of myasthenia gravis patients for thymectomy has been presented Preoperative preparation, conduct of anaesthesia, and care in the postoperative period is discussed Emphasis has been placed on assessment and management of respiratory insufficiency and avordance of anticholinesterase treatment in the immediate and early postoperative recovery period This has 
eliminated the all too common hazard of "cholmergic crisis" The results, suggesting a reduction in operative mortality and morbidity, have been discussed

\section{RÉSUMÉ}

Bien que la valuer de la thymectomie sort controver sée dans le traitement de la myasthénıe grave, plusıeurs mallades sont amélıorés à la suite de cette opération Jusqu'à présent, nous avons pratiqué une thymectomie chez 21 malades, à la suite de cette expérience clinique, nous avons établi une ligne de conduite à l'égard des porteurs de cette pathologie Nous avons modifié tro1s aspects du problème que posent ces malades

(1) l'emploı du décaméthonıum comme épreuve diagnostıque nous a permıs de distunguer trois étapes difféi entes dans l'évolution de la myasthénie grave,

(2) nous avons amélioré l'évaluation et le traitement de l'insuffisance respiratorre,

(3) nous avons abandonné le traitement à l'anticholinestérase au cours des sutes opératorres immédiates Ce geste a fait disparaitre le hasard du dosage excessif (la crise cholinergique)

La préparation du malade comprend l'admission a l'hôpital quelques jours avant l'opération On évalue ses réactions au traitement en donnant des ant1cholinestérasiques, per os On précise la dose optıma Le jour de l'opération, on réduit la dose des antıcholinestérasıques On évite de donner des dépresseurs de la respination dans la prémédication

Nous farsons l'induction de l'anesthésie avec du thropentone (pentothal sodıum) Nous pratiquons une intubation endotiachéale après l'administration d'un myorésolutif dépolarisant Nous maintenons l'anesthésie sort avec le cyclopropane, soit avec l'halothane Nous contrôlons la respiration avec un ventilateur mécanique (Bird) La thymectome se pratque à travers une incision sternalle médiane Après l'opération, certains font une trachéotomie

Au cours des suites opératoires, le malade reçoıt desi soins métıculeux trachéobronchiques

Nous assistons ou contrôlons la iespiration des malades en recourant à la pression positıve intermittente (Bird) jusqu'à satısfaction, ce que nous apprécions par la mesure de l'air courant, du volume-minute (respiromètre de Wright), du $\mathrm{pH}$, de la $\mathrm{pCO}_{2}$ et des $\mathrm{CO}_{3} \mathrm{H}$ (Astrup) Ce trantement peut durer des heures et des jours sans thérapie anticholinestérasique et nous le contınuons jusqu'à ce que nous ayons réussı à déterminer la médication orale opturna

En adoptant cette ligne de condurte au cours des cinq dernières années, nous avons réussı à dimmuer le risque comparatıvement à celuı des huit années anténeures que couvre cette étude Bien davantage souvent, nous donnons ansi aux malades dépénssants leur unıque chance de survie

\section{ACKNOWLEDGMENT}

We would like to express our appreciation to $\operatorname{Dr} G \mathbb{D}$ Saxton, Chief of the Subdivision of Thoracic Surgery, Department of Sulgery, Vancouver General 
Hospital, and Faculty of Medicine, University of Britsh Columbia, for his consultations and the use of several of his patients' records

\section{REFERENCES}

I Herrmani, C, Mulder, D G, \& FonralsRid, E W Thymectomy for Myasthena Gravis Ann Surg 15885 (July 1963)

2 Foldes, F F \& MCNari, $\mathbb{P}$ G Myasthenia Gravis A Gude for Anesthesiologists Anesthesiology 23837 (Nov 1982)

3 VIETs, $\mathbb{R}$ \& Scewar, $\mathbb{R}$ S Thymectomy fol Myasthenia Gravis Springfield Charles C Thomas (1960)

4. Chang, J, Harland, J H, \& Graves, $\mathbb{H}$ B Anaesthetic Aspect of Thymectomy for Myasthenia Gravss Canad Anaesth Soc J 413 (1957)

5 Churchill-Davidson, $\mathrm{H}$ C \& Richardson, A T" The Achon of Decamethonum Iodide (C10) in Myasthenıa Gravis J Neurol Psychıat 15129 (1952)

6 Chang, J, Jenkins, L C, Buckerer, W, \& Zeldowicz, L The Role of an Anaesthetist in a Diagnostic Myasthenia Gravis Clinic To be published

7 Genims, G, Sobei, H J, \& Osserman, $K$ Consecutive Post-mortem Exammations, Myasthenia Gravs 2nd Intern Symp Proc, p 519 Sprnngfield Charles C Thomas (1961)

8 ThifsLefF, S The Mode of Neuromuscular Block Caused by Acetylcholine, Nicotne, Decamethonium and Succunylcholine Acta Physiol Scand 34218 (1955)

9 Churchin-Davioson, H C \& Rrcharoson, A I Myasthenia Gravis Theiapeutic Use of d-tubocurare Lancet \& 1221 (1957)

10 Simpson, J A Myasthemia Gravis A New Hypothesis Scottush Med J 5419 (1980)

11 Nastuck, W L, Puascia, O J, Osserrman, $\mathbb{K}$ E Changes in Serum Complement Actuvity in Patients with Myasthenıa Gravis | Proc Soc Exper Biol Med 105177 (1960) 